\title{
COVID Meets Volvo: The Swedish Public Health Approach to Coronavirus
}

\author{
BINOY KAMPMARK \\ RMIT University \\ bkampmark@gmail.com
}

\begin{abstract}
Sweden has been considered both pioneer and pariah in regard to its approach to the novel coronavirus SARS-CoV-2 and its pandemic disease, COVID-19. While much of Europe went into economic hibernation and rigid lockdown in the first wave of novel coronavirus infections in the spring of 2020, Sweden kept its borders, bars, restaurants, schools, gyms etc. open. Organised children's sporting arrangements were also encouraged, on the basis that socialising and physical activity outweighed the risks posed by COVID-19 to children. Public transportation could still be freely used. Masks were not worn. This paper examines the often controversial tenets of the Swedish public health response to COVID-19, and how widely it has appealed to public health experts and officials in Europe and beyond. Debates within the country are also discussed. What it shows is that, despite rising levels of infection in a second wave in Europe and concessions that it might have even failed, the Swedish model is being adopted by stealth and admired from afar.
\end{abstract}

Keywords: COVID-19, SARS-CoV-2, pandemic, Sweden, public health

\section{Introduction}

On February 1 2020, the Swedish government classified COVID-19 as a disease constituting a danger to society, thereby bringing it within the scope of communicable disease control measures. "The overall objective of the Government's efforts is to reduce the pace of the COVID-19 virus's spread: to 'flatten the curve' so that the large numbers of people do not become ill at the same time" (Prime Minister's Office (Sweden), 2020).

Prime Minister Stefan Löfven, embracing the principle of voluntariness over coercion in targeting the virus, issued warnings to citizens to minimise travel and avoid any nonessential activities. Every individual "in Sweden needs to take individual responsibility. If everyone takes responsibility, we can keep the spread of the virus in check. Follow the authorities' advice: if you have even the slightest symptoms, do not go to work and refrain from meeting other people” (Prime Minister's Office (Sweden), 2020).

Those aged 70 and over, deemed a traditionally vulnerable group - were told by the Folkhälsomyndigheten (Public Health Agency of Sweden) to be particular about their movements and stay at home. In such cases, public transport (buses, trams and the Metro), shopping in supermarkets, frequenting shops and cafes, and visiting areas of 
congregation, should be avoided. Help for buying food, collecting prescriptions and running errands was recommended (Folkhälsomyndigheten, 2021a).

In the Prime Minister's words during a televised speech, "We adults need to be exactly that: adults. Not spread panic or rumours. No one is alone in this crisis, but each person carries a heavy responsibility" (Nikel, 2020). Suggestive in these remarks were two considerations: personal responsibility in terms of behaviour preventing transmission but also responsibility in not spreading rumours about exaggerated harm. As the head of the Public Health Agency, Johan Carlson, explained: "The purpose of our approach is for people themselves to understand the need to follow the recommendations and guidelines that exist." There were "no other tricks before there are available medical measures, primarily vaccines. The Swedish population has taken this to heart" (Osborne, 2020). State epidemiologist Anders Tegnell reiterated the theme in an interview with Nature. "The Swedish laws on communicable diseases are mostly based on voluntary measures. It clearly states that the citizen has the responsibility not to spread the disease" (Paterlini, 2020).

Such language emphasises the cooperative nature of the response between state and citizen responsibility, incorporating the concept of common sense or "folkvett". The emphasis upon voluntary restraint pivots upon such notions of common wisdom or sense, bolstered by the trust shown in the public health information being communicated to the populace. Central to this has been the building up of trust and social capital - "the ability to cooperate without written rules and extensive contracts" (Coleman, 1988; Helsingen et al., 2020). In light of this, expansive coercive public health measures including the lockdown of whole geographical areas, is not only considered unnecessary but a legal impossibility. According to Tegnell, quarantine measures could be applied on a minimal scale to small areas (schools, hotels) but not for large areas and spaces (Paterlini, 2020).

Studies of health systems comparable with Sweden's have also found high degrees of trust in government and health institutions in terms of how risk and hazards are managed. Those risks and hazards are, in turn, culturally coded in terms of their response. "The Swedish justification for their approach was therefore based on culturally relevant concerns and considerations, all informed by a Swedish perception of risk" (Orlowski and Goldsmith, 2020, p. 293). Sweden entered the pandemic crisis with what Esaiasson, Sohlberg, Ghersetti and Johansson claim to be "uniquely high levels of interpersonal trust and high levels of institutional trust" (Esaiasson et al, 2020). To this could also be added the fact that the Public Health Agency and Tegnell initially believed the threat posed by coronavirus to be minimal and entirely manageable. In anonymous, web-based surveys done through Facebook of individuals aged 15 or older from mid-March to mid-April 2020, using the snowball method, researchers found distinctly high trust in the Swedish sample of 508 participants (Helsingen et al, 2020). (3,000 Norwegians were also surveyed.) The Norwegian sample showed "High trust" to 17\%, but for the Swedish sample, it was 37\%. Some 53\% of Swedish participants strongly agreed that they received good information from health authorities, compared to $27 \%$ in Norway.

Unlike the rest of Europe (with the exception of Belarus), the Public Health Agency eschewed an extreme lockdown characterised by hard isolation and large-scale closures of businesses and facilities (Folkhälsomyndigheten, 2021b). Local sports tournaments and matches required no cancellations - exercise and sporting activities 
were seen as necessary, healthy initiatives. Organisers of events and seminars were responsible for conducting a risk assessment and providing information "about good hand hygiene, and access to hand washing facilities for all participants." Importance was placed upon social distancing as a tool of minimising transmission (Carlson, 2020).

Tegnell's opposition towards national lockdowns has been consistent. "It's really using a hammer to kill a fly" (Milne, 2020). In discussing lockdowns in March 2020, the chief epidemiologist suggested that they could only ever be kept in place "for a very limited amount of time before people get tired" and should be used sparingly. Closing schools and keeping children at home would prove societally damaging to families. Dealing with the pandemic involved treating it like "a marathon not a sprint"; any viable vaccines would only be available, if at all, after a year. National restrictions should be as un-onerous as possible so as to be sustainable; forced lockdowns simply "tied up enormous resources" (quotes in Orange, 2020a and Moody, 2020). As Tegnell explained in an interview with the Financial Times in September, "At the outset, we talked very much about sustainability, and I think that's something we managed to keep to. And also be a bit resistant to quick fixes, to realise that this is not going to be easy" or "a short-term kind of thing, it's not going to be fixed by one kind of measure" (Milne, 2020).

Nevertheless, despite the evidently non-punitive, softer nature of the public health directions, Sweden's authorities were not averse to caution. Gatherings were initially limited to 500; the number was then reduced to 50, a measure that has been consistently observed. Bars could only provide table service. Colleges and universities moved to a virtual format in line with recommendations issued on March 18, 2020. As the World Health Organisation's Mike Ryan noted at the end of April, a false narrative had been perpetrated about an absence of any control measures in Sweden in controlling the transmission of COVID-19 (Salo, 2020). The focus in Sweden, rather, is on sensible, voluntary restraint, making sure that large gatherings are avoided, and, where people do gather (those of less than 50 are permitted), physical distancing is observed.

Central to this light non-pharmacological approach is also that of developing resilience and resistance through herd immunity. "When most of a population is immune to an infectious disease, this provides indirect protection - herd immunity - to those who are immune to the disease by acting as a bulwark against further population infection surges" (Orlowski \& Goldsmith, 2020, p. 292). This epidemiological policy is controversial within the Swedish context and beyond, not least because the PHA has not been clear on whether it is, in fact, approving it. The idea initially received traction in Britain where it was openly entertained by UK Prime Minister Boris Johnson, and in the Netherlands by Dutch Prime Minister Mark Rutte (Vogel, 2020). Such a policy is also marked by uncertainty as to what point herd immunity can be said to be achieved. As Daniel M. Altman, Daniel C. Douek and Rosemary J. Boyton have warned, "There is no certainty as to the immunological correlates of antiviral protection or the proportion of the population who must attain them, making it impossible to identify a point when this level of immunity has been reached" (Altman, Douek \& Boyton, 2020, p. 1528).

Tegnell publicly claims that it was never Sweden's intention to pursue a "herd immunity" policy, though his private correspondence, notably in rationalising keeping 
schools open, suggests otherwise (Vogel, 2020). Publicly, he opined that such a pursuit would be immoral as no infectious disease had ever been "fully halted by herd immunity without a vaccine" (Moody, 2020). But in his April interview with Nature, he simply assumed that all countries would eventually be seeking to reach herd immunity, with Sweden intent on reaching "it in a different way" (Paterlini, 2020). Other remarks suggest that Sweden's resilience has been based, in part, on improved immunity levels. Immunity, for instance, could "put the brake" on spikes of infections (Milne, 2020). In April, Karin Ulrika Olofsdotter, Sweden's ambassador to the United Nations, was more explicit about the policy on US National Public Radio, with specific reference to Stockholm's population. "About 30 percent of people in Stockholm have reached a level of immunity." Daringly, she suggested that, "We could reach herd immunity in the capital as early as next month" (Mai, 2020).

\section{The evolving picture}

The numbers of COVID-19 cases in Sweden have not been negligible. From the first recorded case on February 4, 2020, the total, as of March 30, 2020, came to 4,028 (Steward, 2020). Deaths come in at 146, though a disproportionate number were registered in a Somali community located in less commodious quarters with extended families (Pancevski, 2020). Modelling used in a March 2020 study by Imperial College London supplied the springboard for some dire predictions. Paul Franks and Peter Nilsson, both epidemiologists based at Lund University, contrasted that modelling with the PHA's focus on "surge requirements". "From these simulations, it is clear that the Swedish government anticipates far fewer hospitalisations per 100,000 of the population than predicted in other countries, including Norway, Denmark and the UK" (Franks \& Nilsson, 2020). The observations by Franks and Nilsson are filled with characteristic scientific caution. Using British variants suggested a higher death toll for Sweden, though the authorities seem to be holding to the point that most infected people would show no symptoms, leaving one in five requiring a stint in hospital.

Franks even went so far as to suggest that Sweden would be facing 85,000 deaths; a research team of Uppsala, using the Imperial College Model, suggested 40,00o deaths by the start of May and possibly 100,000 by August (Flaxman et al., 2020). This rate was not borne out (Radio Sweden, 2020; Nelson, 2020). As of 4 May, the death toll stood at 2,680 - still high relatively speaking to Nordic countries but better than many countries in the EU.

Despite the highest death toll of the Nordic countries, Tegnell was initially confident that the "strategy" has worked well, with Sweden showing a relatively flat curve of infection relative to Italy and Spain. "We want to slow down the epidemic until Sweden experiences a sort of peak, and if the peak is not too dramatic we can continue" (Skjeseth, 2020). Over the summer of 2020, some success was achieved in slowing the spread, largely because an estimated 1.5 million "self-isolated, largely the elderly and those in risk groups" (Bjorklund \& Ewing, 2020).

The approach did see a tale of two patterns of infection. In the period from March till June, the rest of Europe had seemingly benefitted from extreme to tough lockdowns in reducing the infection rate. In Sweden, the death rate was rising and looked to be approaching that of Italy. While countries such as Spain, France and the UK, and the European Union more collectively had flattened the curve over June and July, Sweden's numbers grew (Milne, 2020). Denmark closed its borders to the country, 
leading the New York Times to call Sweden "a pariah state" (Erdbrink, 2020a). The death rate in aged homes proved horrendous despite Tegnell's age segregation strategy and made the populist Sweden Democrats demand Tegnell's resignation. But the number of case infections began to fall. In August 2020, David Goldsmith declared the Swedish policy a failure: the prediction by the PHA that $40 \%$ of Stockholm's population would acquire the disease and duly generate sufficient antibodies had not come to pass. The number was closer to $15 \%$. A warning was duly noted: "We in the UK would do well to remember we nearly trod the same path as Sweden, as herd immunity was often discussed here in early March" (Royal Society of Medicine, 2020).

By the start of September, the pattern had seemingly been reversed. The EU was battling a resurgence of numbers. Countries debated how to cope with rising infections without re-imposing lockdowns. Papers such the Expressen gloated that the Swedish approach had worked. Tegnell was proud, even with the rise of infections in October, that citizens had made appropriate adjustments in the name of the sustainable policy. "Swedes have changed their behaviour more markedly than almost any other Europeans. We are travelling less than [people in] neighbouring countries. During the spring roughly $40 \%$ of employees worked from home" (Moody, 2020). Then came November, which saw a surge of hospitalisations, deaths and infections in Sweden. The death rate remained lower than Spain and Britain but 10 times higher than Norway and 5 times that of Denmark. On November 25, 6,066 new cases and 10 deaths were recorded; November 26, 5,464 cases and 3 new deaths. ${ }^{1}$ Opponents of the Swedish model viewed these figures as a failure. Eric Orlowski and David Goldsmith are particularly pointed on the issue of the failure of herd immunity. The authors do, however, concede that more time is needed to assess the impacts of the respective policies. Despite making "critical remarks, there is neither justification for schadenfreude, nor for Swedes to feel unduly sheepish about their folkvett" (Orlowski \& Goldsmith, 2020, p. 297).

\section{Epidemiological dissent}

The Swedish model laid the grounds for an epidemiological battle both within Sweden and outside the country. An April 2020 petition featuring over 2,000 doctors, scientists and academics, including figures such as Nobel Foundation chairman, Prof. CarlHenrik Heldin, called for more aggressive measures. "It is risky to leave it to people to decide what to do without any restrictions," opined Joacim Rocklöv, an epidemiologist based at Umeå University. "As can be seen from other countries this is a serious disease, and Sweden is no different than other countries" (Pancevski, 2020). Virologist Cecelia Söderberg-Nauclér of the Karolinska Institute wondered, "No one has tried this route, so why should we test it first in Sweden, without informed consent?" (Reuters, April 4). Söderberg-Nauclér has not held back in her views, claiming that the government has committed grave errors in responding to a pandemic. "We're not testing enough, we're not tracking, we're not isolating enough - we have let the virus loose" (Robertson, 2020). In so doing, Sweden, she argued, had been placed on the path to catastrophe. To avoid a lockdown, a mass-testing approach as adopted by South Korea would have to be adopted.

\footnotetext{
${ }^{1}$ The evolving figures are available at Folkhälsomyndigheten, Antal fal av covid-19 i Sverige, https://experience.arcgis.com/experience/09f821667ce64bf7be6f9f87457ed9aa.
} 
On April 14, 22 Swedish researchers submitted another open letter of concern to the Dagens Nyheter taking issue with the Public Health Agency's approach, and urging government intervention with "swift and radical measures" along the lines undertaken by the country's neighbours. "In Sweden, there are now ten times more people dying than in neighbouring Finland where coffee shops and restaurants are closed." Other comparisons were also cited, with a focus on the last three days before the Easter vacation. Between April 7 and 9, 2020, "10.2 people per million inhabitants died of COVID-19 each day in Sweden." For the same number in Italy, it was 9.7; in Denmark, 2.9; Norway, 2.0 and Finland 0.9 (Dagens Nyhetter, 2020).

The effort failed to have an effect on the standing of either Tengell's policy or himself. Tegnell maintained that the figures cited by his critics were marred by "a number of fundamental errors". Country comparisons, he argued, were always plagued by risky and false assumptions. "The death figures they quote are incorrect, they do not match the Swedish death figures" (Svt Nyheter, 2020a). For Tegnell, this seemed as much a battle against the novel coronavirus as a battle of models and changing circumstances that might be specifically relevant to Sweden' singular circumstances. COVID-19 prediction models, for instance, initially relied on the examples in China and Italy, building upon data gathered from previous Ebola outbreaks, SARS and MERS. Other factors affecting the models involve considerations of demography and evidence of community transmission, the latter being initially unclear in Sweden. An inescapable fact is that Sweden has one major metropolitan area; any accurate modelling would require material specific to that. Ways of interaction between generations would also have to be considered. In Sweden, less intergenerational contact would lessen the risk to the elderly. More than half of Sweden's households consist of one person, another telling factor (Savage, 2020).

Despite Tegnell's confidence, dissent from the Swedish model in the country persisted. Kelly Bjorklund, a human rights and public policy advocate, and Andrew Ewing, professor of molecular biology and chemistry at the University of Gothenburg, have been repeatedly scathing in their review of the Swedish model. Writing in October 2020, the authors took issue with the refusal of the government to implement "early and strong measures to safeguard the population". Despite the issue of such a policy being "hotly debated" in Sweden, the authors were confident that it would "result in a net failure in terms of death and suffering." Figures, as they stood on October 13, noted a per capita death rate of 58.4 per 100,000, making it the twelfth highest in the world (excluding Andorra and San Marino) (Bjorklund \& Ewing, 2020).

A study published by the Journal of the American Medical Association that same month was also far from encouraging. The study, authored by Alyssa Bilinski and Ezekiel Emanuel, was seen by Bjorklund and Ewing as significant for illustrating similarities between the US and Swedish responses, along with their failings. They preferred the policy models of Denmark, Finland, Norway, South Korea, Japan and Taiwan, where early lockdowns and/or extensive testing and tracing regimes were deployed, "saved lives and limited damage to their economies" (Bjorklund \& Ewing, 2020). Reference is also made to a study on Stockholm's wastewater published on October 5 challenging the proposition that increased average daily cases of $173 \%$ from September 2-8 to Sept. 30-Oct.6, with the number being 405\% for Stockholm over that seem period was due to increased testing (Bjorklund \& Ewing, 2020; KTH, 2020). 
Another public intervention was made on November 13, 2020 in the daily Aftonbaldet, involving a plea by 27 Swedish scientists and doctors that the PHA's advice be overridden by political fiat. Tegnell's firm response: "No, we will keep to this path. This is how we work in Sweden. We have big understanding for this and a huge adherence to the rules" (Ahlander, 2020).

Coming to the close of November, the state epidemiologist had to concede that the spread of infection had assumed the form of a second wave, contrary to its report to the government on September 1, which claimed that, "The most likely development in the spread of COVID-19 in Sweden over the next year is a relatively low general spread combined with local outbreaks" (Svennson, 2020). In an interview with Aftonbladet, the country's chief epidemiologist lamented the absence of extensive data on the pandemic in sharp contrast to the extensive material weather forecasters could draw upon. The best that the health authorities could do was deal with scenarios (Svennson, 2020).

\section{Tegnell and controversy}

The COVID-19 pandemic has drawn out the controversies of pandemic governance. How broad is the role given to the state health officer? In Sweden, discretion is vast, and institutional trust in the position clear. Politicians defer to such expertise. But doing so leaves one at the mercy of state medical and epidemiological opinion, and any peculiarities that might characterise it. Some literature even argues that Tegnell's role has moved beyond that of being a mere public health decision maker to being that of a politician (Andersson \& Aylott, 2020).

Despite having a large, possibly even majority, following, Tegnell's own approach has been marred by controversy. Among some members of the Swedish epidemiological community he is regarded as dogmatic and obstinate. He has made a set of misjudgements on aged care, levels of immunity (in Stockholm) and the possible severity of the earlier European lockdowns. In September, his credibility took a bruising when he linked the country's death toll to the standard, seasonal flu season rather than SARS-CoV-2. His reasoning was based on a discredited YouTube video by an anti-lockdown, diet faddist from Ireland (Orange, 2020a).

Flashpoints of disagreement also arose regarding various non-pharmacological measures. Tegnell has advocated openly against the wearing of face masks in curbing viral spread. According to Tegnell, "Face masks are an easy solution, and I'm deeply distrustful of easy solutions to complex problems" (Milne, 2020). He has been careful to avoid deep engagement with the extant literature on mask efficacy. "It's fascinating how few studies there are on this," he told Reuters in mid-November. "And if you look at the countries with ... strict rules for wearing masks, it's difficult to see that they have fared well" (Ahlander, 2020).

Tegnell's anti-mask concerns were expressed on April 5, 2020 in an email to Mike Catchpole, chief scientist at the European Centre for Disease Control and Prevention, claiming to be "worried about the statement ECDC has been preparing about masks." To encourage the wearing of facemasks would suggest "that the spread is airborne which would seriously harm further communication and trust among the population and health care workers" (Bjorklund \& Ewing, 2020). The ECDC was not moved by Tegnell's concerns, recommending the use of face masks in public which "may serve as 
a means of source control to reduce the spread of the infection in the community by minimising the excretion of respiratory droplets from infected individuals who have not yet developed symptoms or who remain asymptomatic" (European Centre for Disease Prevention and Control, 2020). In the event of supply problems, the use of non-medical masks made of substitutes such as textiles might be considered, given the need to prioritise medical face masks for health professionals. While taking longer to shift its view on the use of masks, the World Health Organization also revised its stance in June 2020 to encourage the use of masks (Ellis, 2020).

The firm line against the wearing of masks by the public health authorities became a subject of interest in an October exchange between health officials and the King and Queen of Sweden on their visit to Karolinska University Hospital. Queen Silvia was perplexed. "I think many want to know why we are not recommended to wear them because there are demands on them in so many countries," she suggested. The doctors present put forth the official Swedish position that masks could increase the risk of infection, despite the intention of stemming transmission. "I do not think it seems that anyone can explain so that you actually understand," came the response from the King, Carl XVI Gustaf (Mattsson, 2020).

The King received further clarification from Tegnell himself. Sweden's most prominent public health officer impressed upon the monarch that it was more important to focus on physical distancing. Evaluating face protections in proximity to individuals was difficult, given an absence of decent studies on the subject. Several countries with "a very large spread of infection have ... legislation on oral hygiene for long periods. So it is quite obvious that the masks are not going to save us from the pandemic" (Mattsson, 2020). In making such a claim, Tegnell had confined existing literature on the subject to the margins. Such efforts did not convince the King, who did not shy away in his annual Christmas address in admitting that the Swedish government had failed in its pandemic policies (Svt Nyheter, 2020b).

\section{The Swedish model's appeal}

The appeal of the Swedish model has been evident through Europe and beyond, notably in circles emphasising the consequences of severe lockdowns (loss of freedom of movement; economic harm; the health outcomes of coerced isolation). Indeed, Tegnell has been transformed, for many Swedes, into something unthinkable for the public health experts in other countries. In Sweden, T-shirts featuring Tegnell as a medieval liberator or modern action figure are available for purchase; pages of support and admiration abound on Facebook (Losttorpedo, 2020). Tegnell's point, throughout, is that his approach is less radical than the shock caused by global lockdown formulas responsible for the worst economic crisis since the Great Depression.

Sympathy for Tegnell's model could be found amongst certain European epidemiologists who agreed with the proposition that the lockdown was merely a postponement of the inevitable resurgence of infections. In the initial stages, Britain's chief scientific advisor Sir Patrick Vallance had much praise for the approach, having made similar suggestions to UK Prime Minister Boris Johnson during the "herd immunity" phase of discussions (Pancevski, 2020). In Norway, epidemiologist Eiliv Lund accused his counterparts of simply "pushing the problem out in front of us". The Swedish approach had the merits of ensuring a higher infection rate "and thus a higher immunity" (Orange, 2020b). Danish epidemiologist Christian Wejse lauded Tegnell's 
infection formula, suggesting that the number of immune Swedes might be triple those of Danes. This would mean that Sweden "will be in a better situation if there's a new wave" (Orange, 2020b). It was also seductive to certain politicians mindful of economic priorities. Finland's Osmo Soininvaara, a former minister and member of the Helsinki City Council, saw more merit in Tegnell's approach than his colleagues. In his view, "once the coronavirus crisis is over, the number of deaths in Sweden and Finland [will be] the same. The difference is that in Sweden the death toll [will have been] reached faster. And our economy is in ruins, but the Swedish one will be the strongest in Europe" (Vanttinen, 2020).

Former prime ministers such as Australia's Tony Abbott, who looked with alarm at the Stage 4 lockdown measures being practised in the city of Melbourne after a second COVID-19 surge at the end of June 2020, were also convinced. In a speech to the conservative London-based Policy Exchange think tank in September 2020, Abbott argued that governments in general, with the exception of Sweden, had approached the coronavirus "like trauma doctors; instead of thinking like health economists, trained to pose the uncomfortable questions about a level of deaths we might have to live with". The Victorian government, he argued, had put 5.5 million Melburnians "into virtual house arrest, under night-time curfew, and banned at other times from leaving home for more than an hour a day, or from travelling more than five kilometres." Such lockdowns might reduce instances of disease but not eliminate it: "the result is not just a stop-start economy, but a stop-start life" (Abbott, 2020). Abbott suggested a two-fold approach: stressing voluntary decisions made by citizens on how best they manage pandemic risk (the Swedish model), and the necessary exposure to health risks akin to the survival of the fittest. Vulnerability becomes part of a calculus, measured against a range of variables. Australian lockdown efforts to prevent what were predicted to be 150,000 deaths were, suggested Abbott, insensibly generous to the elderly. "If the average age of those who would have died is 80 , even with roughly 10 years of expected life left, that's still $\$ 200,000$ per quality life year - or substantially beyond what governments are usually prepared to pay for life-saving drugs” (Abbott, 2020).

With a surge in coronavirus cases across Europe in the autumn, many European states looked to Sweden and found its model of approaching coronavirus desirable. But praise came more in a whisper than a shout; the Swedish policy has been adopted stealthily even as it is being publicly condemned for its inhumanity. As Antoine Flahault, director of the Institute of Global Health in Geneva puts it, European countries "are more or less following the Swedish model, combined with testing, tracing, and quarantine procedures the Germans have introduced, but none will admit it" (Erdbrink, 2020b). In November, Tegnell also suggested that Europe and Sweden were essentially converging in their pandemic strategies. "Most countries are trying to do it a bit more like we have done in Sweden." He also admitted that Sweden had learned much from others, "like doing targeted recommendations for different regions" (Ahlander, 2020). With the re-introduction of lockdowns across countries in Europe, this is an observation that requires some circumspection.

\section{Concluding lessons}

In admitting that the Swedish coronavirus policy had been a failure, Prime Minister Löfven suggested a longer view. Only "when we are through the pandemic" could "real conclusions be drawn" (BBC News, 2020). That said, the debate over whether a 
Swedish model of pandemic response is adequate or not has revealed a few, sharp points of contention.

While lockdowns have been firmly eschewed in the Tegnell approach, Sweden's parliament has found itself imposing stricter rules that have come close to mirroring the strategies of its European neighbours. This suggests, on the face of it, that Tengell's previously unchallenged expertise has fallen out of favour. It also suggests that citizens have not been as compliant with the PHA's recommendations as first assumed. In late September 2020, Stockholm's health chief issued a warning that "far too many have stopped following the Swedish Public Health Agency's recommendations" (Orange, 2020a). On January 10, 2021, a new pandemic law came into effect allowing the government to "introduce special restrictions for both certain activities and places" (Regeringskansliet, 2020). Such measures include limiting the numbers at gatherings at such venues as beaches and parks, and the closure of restaurants, shops, or public transport. This is not to say that the authorities would, in fact, exercise such powers, though a legal limit on the number of people permitted in shops and sports facilities (one per 10 square metres) has been imposed (The Local, 2021). The idea of Swedish exceptionalism in public health responses to the pandemic has been challenged, though not totally abandoned.

Tegnell's point about each state being singular in terms of assessing infection and response remains a valid one. Models of infection rates between states vary and are not necessarily commensurate to each other. Given correlations between COVID-19 mortality and age, specific consideration would have to be made to the country's specific demographics. Geography and population density would also be significant, making a comparison using an island continent like Australia to nations bordered by other states flawed. Those with less population density (such as Norway) could not be accurately paired against the United States (Juhrs, 2020). Most problematic of all is the central assumption of herd immunity in this model of public health response. Such an approach is both scientifically uncertain and ethically suspect in privileging the fittest. The hope in doing so is that the vulnerable will be eventually protected by citizens with sufficient anti-bodies. Such a policy did not help the elderly and those with comorbidities in the care sector. Tegnell, along with other public health officials, has privately endorsed a herd immunity program but publicly rejected it.

Until successful mass inoculation takes place, the Swedish model, however controversial, will remain significant. Countries keen on minimising disruptions to economic growth, schooling and civic, social and sporting activities will see merit in it. The concern, as ever, is to identify the most appropriate form of managing pandemic risk in balancing the harms caused to society through imposing, or not, as the case may be, lockdowns while still undertaking other less intrusive forms of health surveillance and control.

\section{References}

Abbott, T. (2020, September 1). Australia and the Coronavirus. Keynote Speech, Policy Exchange (London). https://policyexchange.org.uk/wp-content/uploads/Australiaand-the-Coronavirus-Crisis.pdf

Andersson, S. \& Aylott, N. (2020) Sweden and Coronavirus: Unexceptional Exceptionalism. Social Sciences, 9(12), 1-18. https://www.mdpi.com/2076-0760/9/12/232/html 
Ahlander, J. (2020, November 14.) Second wave, same strategy: Swedish COVID-19 czar defiant despite second surge. Reuters. https://www.reuters.com/article/healthcoronavirus-sweden-tegnell/second-wave-same-strategy-swedish-covid-19-czardefiant-despite-surge-idINKBN27U03Y

Altmann, D. M., Douek, D. C., \& Boynton, R. J. (2020, May 16). What policy makers need to know about COVID-19 protective immunity. The Lancet, 395 (10236), 1527-1529. https://doi.org/10.1016/So140-6736(20)30985-5

BBC News. (2020, December 17. Coronavirus: Swedish King Carl XVI Gustaf says coronavirus approach 'has failed'. https://www.bbc.com/news/world-europe55347021 .

Bjorklund, K. \& Ewing, A. (2020, October 14). The Swedish COVID-19 Response Is a Disaster. It Shouldn't Be a Model for the Rest of the World. Time. https://time.com/5899432/sweden-coronovirus-disaster/

Carlson, J. (2020). The Swedish strategy about COVID-19. Director General of the Public Health Agency of Sweden. https://www.folkhalsomyndigheten.se/the-public-healthagency-of-sweden/communicable-disease-control/covid-19/covid-19--the-swedishstrategy/.

Coleman, J. S. (1988) Social Capital and the Creation of Social Capital. American Journal of Sociology, 94: Supplement: Organizations and Institutions: Sociological and Economic Approaches to the Analysis of Social Structure, S95-S120. http://www.jstor.org/stable/2780243

Dagens Nyhetter (2020, April 14). 22 forskare på DN Debatt: 'Folkhälsomyndigheten har misslyckats - nu måste politikerna grap in'. https://www.dn.se/debatt/folkhalsomyndigheten-har-misslyckats-nu-mastepolitikerna-gripa-in/.

Ellis, R. (2020, June 8). WHO Changes Stance, Says Public Should Wear Masks. WebMD. https://www.webmd.com/lung/news/20200608/who-changes-stance-says-publicshould-wear-masks.

Erdbrink, T. (2020a, June 22.) Sweden Tries Out a New Status: Pariah State. The New York Times. https://www.nytimes.com/2020/06/22/world/europe/sweden-coronaviruspariah-scandinavia.html.

Erdbrink, T. (2020b, September 29). Vilified Early Over Lax Virus Strategy, Sweden Seems to Have Scourge Controlled. The New York Times.

https://www.nytimes.com/2020/09/29/world/europe/sweden-coronavirusstrategy.html.

Esaiasson, P., Sohlberg, J. Ghersetti, M. \& Johannsson, B. (2020) How the coronavirus crisis affects citizen trust in institutions and in unknown others: Evidence from 'the Swedish experiment'. European Journal of Political Research. https://ejpr.onlinelibrary.wiley.com/doi/10.1111/1475-6765.12419.

European Centre for Disease Prevention and Control. (2020, April 8). Using face masks in the community - Reducing COVID-19 transmission from potentially asymptomatic or pre-symptomatic people through the use of face masks. ECDC. https://www.ecdc.europa.eu/en/publications-data/using-face-masks-communityreducing-covid-19-transmission.

Flaxman, S., Mishra, S., Gandy, A. et al. (2020, March 30). Report 13: Estimating the number of infections and the impact of non-pharmaceutical interventions on COVID-19 in 11 
European countries," Imperial College COVID-19 Response Team. https://www.imperial.ac.uk/media/imperial-college/medicine/sph/ide/gidafellowships/Imperial-College-COVID19-Europe-estimates-and-NPI-impact-30-032020.pdf.

Folkhälsomyndigheten (2021a, January 9). Groups at risk of serious illness. https://www.folkhalsomyndigheten.se/the-public-health-agency-ofsweden/communicable-disease-control/covid-19/protect-yourself-and-others-fromspread-of-infection/covid-19-and-at-risk-groups/.

Folkhälsomyndigheten (2021b, March 9). COVID-19. https://www.folkhalsomyndigheten.se/the-public-health-agency-ofsweden/communicable-disease-control/covid-19/.

Franks, P. W. \& Nilsson, P. M. (2020, March 28). Sweden under fire for "relaxed" coronavirus approach - here's the science behind it. The Conversation. https://theconversation.com/sweden-under-fire-for-relaxed-coronavirus-approachheres-the-science-behind-it-134926.

Helsingen, L. M., Refsum, E, K. G., Dagrum, Løberg, M., Bretthauer, M., Kalager, M., Louise Emilsson, L. \& for the Clinical Effectiveness Group. (2020). The COVID-19 pandemic in Norway and Sweden: threats, trust, and impact on daily life: a comparative survey. BMC Public Health, 20, 1597.

https://bmcpublichealth.biomedcentral.com/articles/10.1186/s12889-020-09615-3.

Jurhs, A. (2020, October 12). Study Limitations and Conclusions. Letter in response to Alyssa Bilinski and Ezekiel J. Emanuel. COVID-19 and Excess All-Cause Mortality in the US and 18 Comparison Countries. Journal of the American Medical Association. https://jamanetwork.com/journals/jama/fullarticle/2771841.

KTH (2020, October 5.) Avloppsvatten visar stor ökning av covid-19 i Stockholm. https://www.kth.se/aktuellt/nyheter/avloppsvatten-visar-stor-okning-av-covid-19-istockholm-1.1016275

Local, The. (2021, January 11). The Swedish coronavirus laws you need to know about in 2021. https://www.thelocal.se/20210111/coronavirus-law-changes-to-expect-in2021/.

Losttorpedo (2020). Anders Tegnell: Action Hero Sweden Essential T-Shirt. https://www.redbubble.com/i/t-shirt/Anders-Tegnell-Action-Hero-Sweden-bylosttorpedo/48491935.FB110.

Mai, H. J. (2020, April 26). Swedish Ambassador Says Stockholm Expected to Reach "Herd Immunity” In May. National Public Radio (NPR). https://www.npr.org/2020/04/26/845211085/stockholm-expected-to-reach-herdimmunity-in-may-swedish-ambassador-says.

Mattsson, S. (2020, October 15). Anders Tegnell riktar hårda ord till kungen: "Måste komma ihåg”. Svensk Dam. https://www.svenskdam.se/kungligt/anders-tegnell-riktarharda-ord-till-kungen-maste-komma-ihag/6443344.

Milne, R. (2020, September 11). Anders Tegnell and the Swedish Covid experiment. Financial Times. https://www.ft.com/content/5cc92d45-fbdb-43b7-9c66$\underline{26501693 a 371 .}$

Moody, O. (2020, October 29). Coronavirus: Sweden's push for herd immunity immoral, says covid chief. The Australian. 
Nelson, F. (2020, May 4). Sweden tames its "R number" without lockdown. The Spectator. https://www.spectator.co.uk/article/sweden-tames-its-r-number-without-lockdown.

Nikel, D. (2020, March 30). Why Sweden's Coronavirus Approach is so different from others. Forbes. https://www.forbes.com/sites/davidnikel/2020/03/30/why-swedenscoronavirus-approach-is-so-different-from-others/\#3cfcedob562b

Orange, R. (2020a, October 5.) The twisty tale of Dr Tegnell. Prospect Magazine. https://www.prospectmagazine.co.uk/magazine/the-twisty-tale-of-dr-tegnell

Orange, R. (2020b, May 1). Will Sweden's herd immunity experiment pay off? Prospect Magazine. https://www.prospectmagazine.co.uk/magazine/will-swedens-herdimmunity-experiment-pay-off.

Orlowski, E. J. W. \& Goldsmith, D. J. A. (2020). Four months into the COVID-19 pandemic, Sweden's prized herd immunity is nowhere in sight. Journal of the Royal Society of Medicine, 113(8), 292-298. https://doi.org/10.1177/0141076820945282

Osborne, H. (2020, September 10). Sweden's Public Health Director Explains Why Lack of Lockdown Was a Success. Newsweek. https://www.newsweek.com/sweden-covidlockdown-success-public-health-1530927.

Pancevski, B. (2020, March 30). Inside Sweden's Radically Different Approach to the Coronavirus. Wall Street Journal. https://www.wsj.com/articles/inside-swedensradically-different-approach-to-the-coronavirus-11585598175.

Paterlini, M. (2020, April 21). "Closing borders is ridiculous": the epidemiologist behind Sweden's controversial coronavirus strategy. Nature.

https://www.nature.com/articles/d41586-020-01098-

x?fbclid=IwAR1a1eseepvgAKL-

V6B1VM918SZcC7sLvLiLQTN2eWf5V2MQzdWV4DDcex4.

Prime Minister's Office (Sweden) (2020.April 6). Strategy in response to the COVID-19 pandemic. https://www.government.se/articles/2020/04/strategy-in-response-tothe-covid-19-pandemic/.

Radio Sweden (2020, March 26.) Large differences in British and Swedish coronavirus calculations.

https://sverigesradio.se/sida/artikel.aspx?programid=2054\&artikel=7437147.

Regeringskansliet. (2020, December 28). Förslag på tillfällig pandemilag för covid-19 skickas till lagrådet. https://www.regeringen.se/pressmeddelanden/2020/12/forslag-patillfallig-pandemilag-for-covid-19-skickas-till-lagradet/.

Robertson, D. (2020, March 31). “They are leading us to catastrophe”: Sweden's coronavirus stoicism begins to jar. The Guardian.

https://www.theguardian.com/world/2020/mar/30/catastrophe-swedencoronavirus-stoicism-lockdown-europe.

Royal Society of Medicine (2020, August 13). COVID-19 - Herd Immunity in Sweden Fails to Materialize. News release. Targeted News Service.

Salo, J. (2020, April 29). WHO lauds lockdown-ignoring Sweden as a "model" for countries going forward. New York Post. https://nypost.com/2020/04/29/who-lauds-swedenas-model-for-resisting-coronavirus-lockdown/. 
Savage, M. (2020, August 22). Why so many young Swedes live alone," BBC Worklife. https://www.bbc.com/worklife/article/20190821-why-so-many-young-swedes-livealone.

Skjeseth, H. T (2020, March 28). Sveriges korona-srategi: Typisk svensk. Urik. NRK. https://www.nrk.no/urix/okt-press-mot-sveriges-korona-strategi-1.14963066.

Stewart, C. (2020, February 4.) Cumulative number of coronavirus cases in Sweden in February 2020. Statistica. https://www.statista.com/statistics/1102203/cumulativecoronavirus-cases-in-sweden/.

Svennson, O. (2020, November 26). Tegnell avfärdar kritiken: Kan inte förstå den. Aftonbladet. https://www.aftonbladet.se/nyheter/a/jBvEjq/tegnell-avfardarkritiken-kan-inte-forsta-den.

Svt Nyheter. (2020a, April 15). Virologen Lena Einhorn och Anders Tegnell möttes i debatt. https://www.svt.se/nyheter/inrikes/virologidoktorn-folkhalsomyndighetens-strategiar-farlig.

Svt Nyheter. (2020b, December 17). Kungen om pandemin: "Jag anser att vi har misslyckats”. https://www.svt.se/nyheter/inrikes/kungen-jag-anser-att-vi-harmisslyckats.

Vanttinen, P. (2020, April 14). Academics criticise government in an open letter. Euractiv. https://www.euractiv.com/section/all/short news/stockholm-academics-criticisegovernment-in-open-letter/.

Vogel, G. (2020, October 9). Sweden's Gamble. Science, 37o(6513), 159-163. https://science.sciencemag.org/content/370/6513/159. 